\title{
Effect of Changing Cement Grade on the Properties of Structural Concrete
}

\author{
C. A. Fapohunda*, B. I. Famodimu, B. C. Adigo, A. S. Jeje \\ Department of Civil Engineering, Federal University, Oye-Ekiti, Nigeria.
}

ABSTRACT: Many research efforts have been carried out, in a quest to produce mix design information that will guide the concrete and construction industry on how to achieve different concrete strengths, using the different grades of cement available. This is with a view to arresting the rampant collapse of buildings in Nigeria. The work presented in this paper is the result of investigation carried out to determine effects of changing cement grade, while casting a structural member, on the strength behaviour of the concrete. Two types of cement grades: $32.5 \mathrm{R}$ and $42.5 \mathrm{R}$ were used for this research. In this investigation, the chemical and physical properties of the cement were determined. Consistency and setting times of mortar specimens from the two cement grades were also determined. Concrete samples made from the two cement grades $32.5 \mathrm{R}$ and $42.5 \mathrm{R}$ were evaluated for workability, density, compressive and tensile strengths at water/cement ratios of $0.40,0.50$ and 0.60 . The results showed that the cement grade 42.5 consistently developed higher densities at all the water/cement ratios considered. This may be as a result of unforeseen additional dead load at the design stage, which would now amount to underestimation of dead load and thus design load. The results also showed that at higher water/cement ratios, the cement grade $42.5 \mathrm{R}$ has densities exceeding the $2400 \mathrm{~kg} / \mathrm{m}^{3}$ recommended by BS 8110 . Furthermore, the concretes produced with cement grades of $32.5 \mathrm{R}$ and 42.5 $\mathrm{R}$ have different strength development pattern and developed different 28-day compressive strength. Thus, it can be concluded that the action of changing the cement grade during concreting, for the same structural member is not supported by the national code, and will not result in safe and durable concrete.

KEYWORDS: Cement grades, Compressive strength, Density, Portland limestone cement, Tensile strength, Workability.

[Received January 23, 2020, Revised July 26, 2020, Accepted August 8, 2020]

Print ISSN: 0189-9546 | Online ISSN: 2437-2110

\section{INTRODUCTION}

Concrete is the most-used material in the building and construction of civil infrastructures, especially for shelters of many types and usages. However, the concrete industry in Nigeria has attracted sustained attentions in recent times, because of frequent building collapse either during construction, or in service with attendant loss of lives and properties. A graphic picture of this trend can be observed from the results of investigations conducted by Omenihu et al. (2016) as presented in Table 1. Although, their work covered a period of up to 2016, it is obvious from Table 1 that collapse of buildings has been on the increase.

The works of Odeyemi et al. (2019) not only extended to, and including 2019, but also identified the causes of such failures. Their works showed that about $90 \%$ of the identified causes are structural in nature. Since most of the buildings were built with concrete, it will not be out of place to investigate the concrete as a material and also question the quality of its individual component. Cement, as the major binder, that contribute in no small measure to the strength of concrete has come under scrutiny for some times on its

*Corresponding author: christopher.fapohunda@fuoye.edu.ng suitability or otherwise of some grades of cement in the production of structural concrete.

Table 1: Summary of collapse buildings and casualties between 1971 -
\begin{tabular}{ccccc}
$\mathbf{2 0 1 6}$ in Nigeria & (Omenihu et al., 2016). & \\
\hline S/No & Year & $\begin{array}{c}\text { Number of } \\
\text { Collapse }\end{array}$ & $\begin{array}{c}\text { Number of } \\
\text { Lives Lost }\end{array}$ & $\begin{array}{c}\text { \% Collapse } \\
\text { Occurrence }\end{array}$ \\
\hline 1 & $1971-1975$ & 2 & 51 & 1.14 \\
2 & $1976-1980$ & 8 & 99 & 4.57 \\
3 & $1981-1985$ & 14 & 71 & 8.00 \\
4 & $1986-1990$ & 15 & 144 & 8.57 \\
5 & $1991-1995$ & 20 & 112 & 11.43 \\
6 & $1996-2000$ & 24 & 175 & 13.71 \\
7 & $2001-2005$ & 23 & 235 & 13.14 \\
8 & $2006-2010$ & 28 & 324 & 16.01 \\
9 & $2011-2016$ & 41 & 244 & 23.43 \\
\hline \multicolumn{7}{c}{ Total } & $\mathbf{1 7 5}$ & $\mathbf{1 4 5 5}$ & $\mathbf{1 0 0}$ \\
\hline
\end{tabular}

Presently, two grades of cement (32.5 R and 42.5 R) are sold in Nigerian market, which engineers are expected to use to obtain appropriate concrete mix design for specific work. To remove any doubt in the minds of those raising concerns, the Council for the Regulation of Engineering in Nigeria (COREN, 2016) informed that both grades are suitable. The body however advised that a lot of research is needed to produce mix design information that will guide the doi: http://dx.doi.org/10.4314/njtd.v17i3.6 
construction industry on how to achieve different strengths of sandcrete and concrete using the different grades of cement available.

Taking up the gauntlet, Adewole et al. (2015) conducted investigations on appropriate mix design using grade $32.5 \mathrm{R}$ and $42.5 \mathrm{R}$. They concluded that the strength class C20/25 which is the minimum concrete strength class recommended for the construction of load-bearing building structural members cannot be produced with 1:2:4 mix ratio and $32.5 \mathrm{~N}$ grade of cement, but with $42.5 \mathrm{~N}$ grade. The work of Joel and Mbapuun (2016), nonetheless showed results in which concrete produced with grade $42.5 \mathrm{~N}$ developed higher strength than that produced with grade $32.5 \mathrm{~N}$. Their results however seemed to contradict that of Adewole et al. (2015), in that concrete produced with $32.5 \mathrm{~N}$ grade and 1:2:4 mix developed a compressive strength higher than $\mathrm{C} 20 / 25$. This result is not strange, knowing that strength of concrete does not depend exclusively on the cement grade alone (Neville, 2011 and Gambhir, 2013).

Other factors come into play. Concrete from 1:2:4 and cement grade $42.5 \mathrm{R}$ will not develop any appreciable strength if: (i) aggregate used failed structural specifications, (ii) not properly compacted and (iii) not well-cured. According to Walker and Bloem (1961), Neville (2011) and Gambhir (2013), the strength of a well-compacted concrete results from the strength of the mortar, the bond between the mortar and coarse aggregate (that is, the properties of interfacial zone), and the strength of the coarse aggregate particle (that is, its ability to resist the stresses applied to it). Added to these facts is that, in Nigeria, many of our behaviors that bothers on inadequate planning and lack of professionalism on the part of the construction company (most especially indigenous contractors) can also make the strengths development of structural concrete to be very unpredictable.

For example, in a situation where casting of slab work was started with say, $42.5 \mathrm{R}$, and mid-way while the concreting is going on, the grade $42.5 \mathrm{R}$ was exhausted, and the supplier brings in $32.5 \mathrm{R}$ to replace it, because grade $42.5 \mathrm{R}$ is no longer available. Thus, the engineer that is in charge of the project is in dilemma in the absence of historic strength development data from the producer (Bamforth et al., 2008), which does not accompany cement that are made in Nigeria. On the other hand, if an engineer is absent, whoever is there will just continue with the casting using the $32.5 \mathrm{R}$ supplied, as if to say that nothing has happened.

This situation was not envisaged by the Code. According to Bamforth et al. (2008), the BS 8110 (1997) assumed that design and construction of concrete will, amongst others: (i) be subject to adequate supervision and quality control procedures, (ii) be carried out by personnel having the appropriate skills and experience, (iii) will involve the use materials and products as specified and (iv) meet the requirements for execution and workmanship as prescribed by relevant code. But there are questions for which answers ought to be provided. Assuming all other concreting conditions remained in place, will concrete produced from both grades develop strength at the same rate? Will concrete produced from these grades be ready for stripping at the same time? Will concrete produced from these grades have the same 28-day compressive strength?
Thus, the aim of this study is to assess the structural implications of changing cement grade during concreting operations on the compressive strength characteristics of structural concrete made from limestone Portland cement grades $32.5 \mathrm{R}$ and $42.5 \mathrm{R}$, using water/cement ratios of 0.40 , 0.50 and 0.60 . Specific objectives involve the investigation of workability, density, compressive strength and tensile strength of concrete made with cement grades $32.5 \mathrm{R}$ and $42.5 \mathrm{R}$ at 7 , $14,28,60$ and 90 days of curing.

\section{MATERIALS AND METHODS}

\section{A. Materials and Mix Proportions}

The materials used for this research work were cement, fine aggregate, coarse aggregate and water. Portland limestone cement of grades $32.5 \mathrm{R}$ named Type 1 (in Table 2) and 42.5 $\mathrm{R}$ named Type 2 (in Table 2), produced to conform to the requirements of CEM II of NIS 444 (2014), as specified by the manufacturer, were used. The fine aggregate used was river sand. The sand was sun-dried and sieved. The sand material passing through sieve no $4(4.75 \mathrm{~mm})$ but retained on sieve no $200(75 \mu \mathrm{m})$ was collected. The coarse aggregate was naturallyoccurring crushed stone obtained from a quarry site in IkoleEkiti. To conform with BS 8110 (1997) recommendations for structural concrete, the maximum size was limited to $20 \mathrm{~mm}$. Portable water was used for the mixing of concrete. For the purpose of this investigation, a concrete mix of 1:2:4 and water/cement ratios of $0.4,0.5$ and 0.6 were adopted. The mix proportion on the basis of this is presented in Table 2 .

\begin{tabular}{ccccccc}
\multicolumn{2}{c}{ Table 2: Mix proportion for the investigation. } \\
\hline Grade & $\begin{array}{c}\text { W/C } \\
\text { Ratio }\end{array}$ & $\begin{array}{c}\text { Mix } \\
\text { Designation }\end{array}$ & $\begin{array}{c}\text { Cement } \\
\left(\mathbf{k g} / \mathbf{m}^{\mathbf{3}}\right)\end{array}$ & $\begin{array}{c}\text { Sand } \\
\left(\mathbf{k g} / \mathbf{m}^{\mathbf{3}}\right)\end{array}$ & $\begin{array}{c}\text { Gravel } \\
\left(\mathbf{k g} / \mathbf{m}^{\mathbf{3}}\right)\end{array}$ & $\begin{array}{c}\text { Water } \\
\left(\mathbf{k g} / \mathbf{m}^{3}\right)\end{array}$ \\
\hline 32.5R & 0.4 & $\mathrm{M}_{14}$ & 343 & 686 & 1372 & 137 \\
(Type 1) & 0.5 & $\mathrm{M}_{15}$ & 343 & 686 & 1372 & 172 \\
& 0.6 & $\mathrm{M}_{16}$ & 343 & 686 & 1372 & 206 \\
42.5R & 0.4 & $\mathrm{M}_{24}$ & 343 & 686 & 1372 & 137 \\
(Type 2) & 0.5 & $\mathrm{M}_{25}$ & 343 & 686 & 1372 & 172 \\
& 0.6 & $\mathrm{M}_{26}$ & 343 & 686 & 1372 & 206 \\
\hline
\end{tabular}

Concrete ingredients were batched by weight, and thoroughly mixed following the suggestion of Gambhir (2013). The concrete was cast into moulds of sizes $150 \times 150$ $\mathrm{x} 150 \mathrm{~mm}$ cube specimens for compression investigation and $150 \mathrm{~mm} \times 300 \mathrm{~mm}$ cylinder specimens for tensile strength assessment. The specimens were then compacted manually. The concrete specimens were demoulded after 24 hours and then moist-cured until the date of testing. Specimens were tested at 7, 14, 28, 60 and 90 days of curing.

\section{B. Methods}

\section{1.) Materials characterization}

Preliminary investigation was conducted to determine the physical properties of aggregate such as the density, specific gravity, water absorption, moisture content, and particle size distribution, for both the fine and coarse aggregate. Chemical analysis was also conducted to determine the oxides composition of the Portland limestone cement. 


\section{2.) Consistency test}

The consistency test was performed to determine the amount of water required to achieve a paste of standard consistence for mortar specimens containing Portland limestone cement of grades $32.5 \mathrm{R}$ and $42.5 \mathrm{R}$. The test was conducted in accordance with BS EN 196-3 (2005) using the Vicat apparatus.

\section{3.) Setting time test}

The investigation of the initial and final setting times of paste containing Portland limestone cement of grades $32.5 \mathrm{R}$ and $42.5 \mathrm{R}$, were evaluated by making use of the water required to achieve the standard consistency of cement paste specimens, as determined from the consistency test in accordance to BS EN 196-3 (2005). The setting times - both initial and final - were then determined for the grades of cement (32.5 $\mathrm{R}$ and $42.5 \mathrm{R}$ )

\section{4.) Workability test}

In order to assess the ease and homogeneity with which freshly mixed concrete with the cements can be mixed, placed, compacted, and finished without segregation and bleeding, slump test was carried out. This property is called workability as per ACI 116R-90 (1994). The experiment was conducted in accordance with the requirements of BS EN 12350: Part 2 (2000).

\section{5.) Density and compressive strength tests}

The density and the compressive strength of concrete specimens containing Portland limestone cement of grades 32.5 $\mathrm{R}$ and $42.5 \mathrm{R}$ were assessed. $150 \times 150 \times 150 \mathrm{~mm}$ cube specimens were used for both tests. The density test was done in accordance with the provisions of BS 12350: Part 6 (2000). Investigation of the compressive strength was carried out in accordance to the provisions of BS EN 12390-3 (2009). In order to determine the compressive strength of the concrete samples, a computerized $2000 \mathrm{kN}$ WAW-2000B compressive strength machine, with accuracy of $\pm 1 \%$ of test force, was used. At the testing date, three (3) specimens were tested, and their mean strength determined. The weight of each concrete cube was measured before testing. The average density of the concrete cube specimens (in triplicate) was obtained by dividing the obtained weight of the samples by their volumes, which is the volume of the cubes.

\section{6.) Tensile strength}

The investigation of the tensile strength of concrete samples with Portland limestone cement of grades $32.5 \mathrm{R}$ and $42.5 \mathrm{R}$ was done with the aid of $150 \mathrm{~mm}$ x $300 \mathrm{~mm}$ cylinder specimens. The test was carried out as per recommendation of BS 12390: Part 6 (2009). A computerized universal testing

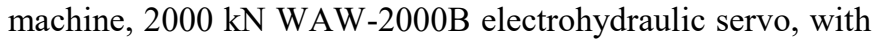
accuracy of $\pm 1 \%$ of test force. Eqn (1) was used to compute the splitting tensile strength.

$$
T_{S}=\frac{2 P}{\pi l d}
$$

In eqn (1), $T_{s}$ is the splitting tensile strength $\left(\mathrm{N} / \mathrm{mm}^{2}\right), \mathrm{P}$ is the maximum applied load (in Newtons) by the testing machine, $l$ is the length of the specimen ( $\mathrm{mm})$, and $\mathrm{d}$ is the diameter of the specimen $(\mathrm{mm})$.

\section{RESULTS AND DISCUSSION}

\section{A. Materials Characterization}

The properties of the aggregates are shown in Table 3. From the table, it can be seen that the specific gravities of sand and gravel are 2.63 and 2.67 respectively. According to Gambhir (2013), the average specific gravity of majority of natural aggregate lie between 2.5 and 2.8. Thus, both the sand and gravel used in this investigation can be considered as natural aggregate. Also, the bulk density, water absorption and the moisture content of both the sand and gravel fell between the ranges used in normal concrete (ACI, 1999). These values are 1280 to $1920 \mathrm{~kg} / \mathrm{m}^{3}$ for density, 0 to $8 \%$ for water absorption, and $0-2 \%$ for sand and $0-10 \%$ for gravel. Also, the coefficient of curvature for both are close to 1 , thus indicating that both are well-graded, while the coefficient of uniformity of less than or equal to 4 recorded for both sand and gravel suggest that both are uniformly graded (Iowa, 2020). Overall conclusion of all of these is that the materials are good for concrete production.

Table 3: The physical properties of the aggregates.

\begin{tabular}{lcc}
\hline \multicolumn{1}{c}{ Properties } & Sand & Gravel \\
\hline Specific Gravity & 2.63 & 2.67 \\
Bulk Density $\left(\mathrm{kg} / \mathrm{m}^{3}\right)$ & 1666.67 & 1641.67 \\
Water Absorption $(\%)$ & 2.00 & 2.00 \\
Moisture Content $(\%)$ & 0.00 & 0.00 \\
Coefficient of curvature $(\mathrm{Cc})$ & 0.88 & 0.98 \\
Coefficient of uniformity $(\mathrm{Cu})$ & 3.00 & 2.43 \\
\hline
\end{tabular}

\section{B. Chemical Analysis}

The chemical analysis of the cement grade $32.5 \mathrm{R}$ and 42 . $5 \mathrm{R}$ are shown in Table 4. From the table, it can be seen that both $32.5 \mathrm{R}$ and $42.5 \mathrm{R}$ have high $\mathrm{CaO}$ in relation to other oxides. The overall oxides composition is in line with similar limestone Portland cement reported by Tosun et al. (2009). The limits of oxides $\left(\mathrm{CaO}, \mathrm{SiO}_{2}, \mathrm{Al}_{2} \mathrm{O}_{3}, \mathrm{Fe}_{2} \mathrm{O}_{3}\right)$ in the Table were according to Neville (2011), as no limits were specified by

Table 4: Oxides composition and compounds of grades of cement.

\begin{tabular}{lccc}
\hline & \multicolumn{2}{c}{ Oement Type } & BS EN 197-1(2000) \\
\cline { 2 - 3 } \multicolumn{1}{c}{ Oxides } & 32.5R (\%) & $\mathbf{4 2 . 5 R ( \% )}$ & (\%) \\
\hline $\mathrm{CaO}$ & 64.20 & 65.55 & 63 \\
$\mathrm{SiO}_{2}$ & 18.92 & 17.89 & 20 \\
$\mathrm{Al}_{2} \mathrm{O}_{3}$ & 5.08 & 4.78 & 6 \\
$\mathrm{~F}_{2} \mathrm{O}_{3}$ & 3.30 & 3.72 & 3 \\
$\mathrm{MgO}$ & 0.92 & 0.85 & \\
$\mathrm{Na}_{2} \mathrm{O}$ & 0.19 & 0.30 & $0.00-5.00$ \\
$\mathrm{~K}_{2} \mathrm{O}$ & 0.42 & 0.42 & \\
$\mathrm{Mn}_{2} \mathrm{O}$ & 0.02 & 0.01 & \\
$\mathrm{SO}_{3}$ & 2.16 & 1.97 & 3.50 \\
$\mathrm{LOI}$ & 2.08 & 1.97 & 5.0 \\
Insoluble Residue & 0.34 & 0.25 & 5.0 \\
\hline
\end{tabular}


BS EN 197-1 (2000) in respect of those oxides. In addition, it can be observed from Table 4 that the chemical compositions conform to the following requirement of BS EN 197-1 (2000), namely: $\mathrm{SO}_{3}$ less than $4.0 \%$; loss on ignition of less than $5 \%$ and insoluble residue of less than $5.0 \%$

\section{Physical Properties of Portland Limestone Cement and Mortar}

The physical properties of the grades of cement and that of their mortars are presented in Table 5. It can be observed from this table that both grades of cement have similar the specific gravity and fineness. However, grade $42.5 \mathrm{R}$ has a higher consistency. This means higher amount of water is required by grade $42.5 \mathrm{R}$ to achieve a standard consistency. Also, the initial setting times of 170 and 175 minutes for 32.5 $\mathrm{R}$ and $42.5 \mathrm{R}$ respectively, are higher than 60 minutes stipulated by BS EN 197-1 (2000). In relation to the final setting time, both the BS 12 (196) and EN 197-1 (2000) have to limits or recommendations. This is in agreement with Neville (2011) who observed that limits on the final setting time no longer appear in the European or ASTM standards. It can thus be concluded that the final setting times obtained for both $32.5 \mathrm{R}$ and $42.5 \mathrm{R}$ are acceptable.

Table 5: Some physical properties of portland limestone cement and mortar.

\begin{tabular}{lcc}
\hline Properties & 32.5 R & $\mathbf{4 2 . 5} \mathbf{~ R}$ \\
\hline Specific Gravity & 3.14 & 3.12 \\
Fineness (\%) & 90 & 90 \\
Consistency (\%) & 29.5 & 33 \\
Initial Setting Time (minutes) & 170 & 175 \\
Final Setting Time (minutes) & 362 & 342 \\
\hline
\end{tabular}

\section{Workability}

Workability, according to Neville and Brooks (1987), is required for maximum compaction necessary for the development of compressive strength, and it is vital to achieve a maximum possible density. The slump characteristics of concrete specimens with different grades of Portland limestone cement, at different water/cement ratios are presented in Table 6.

\begin{tabular}{|c|c|c|c|}
\hline \multirow{2}{*}{$\begin{array}{l}\text { Cement } \\
\text { grade }\end{array}$} & \multicolumn{3}{|c|}{ Water/cement ratios } \\
\hline & 0.40 & 0.50 & 0.60 \\
\hline $32.5 \mathrm{R}$ & 0.0 & $5 \mathrm{~mm}$ & $20 \mathrm{~mm}$ \\
\hline $42.5 \mathrm{R}$ & 0.0 & $5 \mathrm{~mm}$ & $20 \mathrm{~mm}$ \\
\hline
\end{tabular}

For both grades of cement the slump increased with water/cement ratio. Also, both grades of cement have similar values in slump, and exhibited true slump. For the slump values of between 0 and $20 \mathrm{~mm}$ recorded at the considered water/cement ratios, the workability of both cement grades is to be considered as low (Neville, 2011 and Gambhir, 2013).

\section{E. Density of Concrete Specimens made with Different Grades of Portland Limestone Cement}

The pattern of density development of concrete made with $32.5 \mathrm{R}$ and $42.5 \mathrm{R}$ at all the water/cement ratios is shown in Figure 1 for density of concrete at water/cement ratio of 0.40 . At all the water/cement ratios, the cement grade $42.5 \mathrm{R}$ consistently developed higher densities at all the curing days. The implication of this is that if there is change in cement grade during concreting operations for the casting of a structural element, two types of densities will result.

The BS 8110 (1997) governing design of structural concrete in Nigeria does not envisage this situation. Only one type of density is in view when using the BS 8110 (1997). Also, looking at the numerical values of the densities (in $\mathrm{kg} / \mathrm{m}^{3}$, with standard deviations of between 28.33 to $33.21 \mathrm{~kg} / \mathrm{m}^{3}$ ) developed at all the water/cement ratios as shown in Tables 7 -9 , some developments are worthy of attention. The obtained densities increased with water/cement ratios, especially for cement grade of $42.5 \mathrm{R}$, exceeding the limit of concrete density for normal concrete.

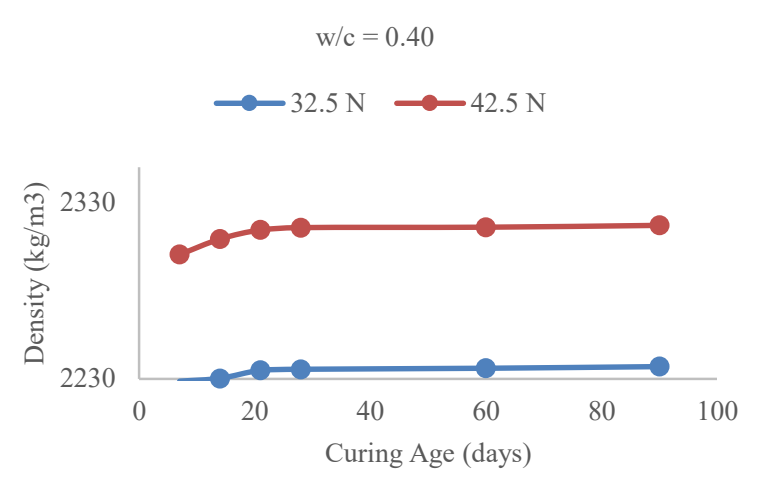

Figure 1: A Typical Density development of Concrete Specimens made with Cement grades 32.5 $\mathrm{R}$ and 42. $5 \mathrm{R}$.

Table 7: Density of concrete specimens made with cement grades at w/c

\begin{tabular}{lllllll}
\multicolumn{7}{c}{ ratio $=\mathbf{0 . 4 0}$. } \\
$\begin{array}{lllllll}\text { Cement } \\
\text { grade }\end{array}$ & $\mathbf{7}$ & $\mathbf{1 4}$ & $\mathbf{2 1}$ & $\mathbf{2 8}$ & $\mathbf{6 0}$ & $\mathbf{9 0}$ \\
\hline $\mathbf{3 2 . 5 R}$ & 2228.57 & 2230.23 & 2234.87 & 2235.45 & 2236.03 & 2236.97 \\
$\mathbf{4 2 . 5 R}$ & 2300.46 & 2309.29 & 2314.43 & 2315.76 & 2315.98 & 2317.02 \\
\hline
\end{tabular}

Table 8: Density of concrete specimens made with cement grades at w/c

\begin{tabular}{|c|c|c|c|c|c|c|}
\hline $\begin{array}{l}\text { Cement } \\
\text { grade }\end{array}$ & 7 & 14 & 21 & 28 & 60 & 90 \\
\hline $32.5 \mathrm{R}$ & 2373.44 & 2378.29 & 2381.77 & 2387.39 & 2392.99 & 2400.47 \\
\hline $42.5 R$ & 2406.64 & 2409.23 & 2411.62 & 2415.81 & 2420.83 & 2422.05 \\
\hline
\end{tabular}

Table 9: Density of concrete specimens made with cement grades at w/c

\begin{tabular}{lllllll}
\multicolumn{7}{c}{ ratio $=\mathbf{0 . 6 0}$. } \\
$\begin{array}{lllllll}\text { Cement } \\
\text { Grade }\end{array}$ & $\mathbf{7}$ & $\mathbf{1 4}$ & $\mathbf{2 1}$ & $\mathbf{2 8}$ & $\mathbf{6 0}$ & $\mathbf{9 0}$ \\
\hline 32.5R & 2390.04 & 2390.89 & 2392.06 & 2435.87 & 2439.05 & 2441.78 \\
$\mathbf{4 2 . 5 R}$ & 2473.03 & 2477.49 & 2480.05 & 2482.97 & 2483.01 & 2483.89 \\
\hline
\end{tabular}


The British standard BS 8110 (1997) which governs the design of structural concrete recommends a density of $2400 \mathrm{~kg} / \mathrm{m}^{3}$. This value is used for estimation of dead loads to obtain the design loads. Thus, using a density of $2400 \mathrm{~kg} / \mathrm{m}^{3}$, while the actual density is in excess of $2400 \mathrm{~kg} / \mathrm{m}^{3}$ will lead to underestimation of design loads. The effects could be catastrophic. Within the same grade of concrete, the developed densities increased with water/cement ratios. This can be seen in Figures 2 and 3.

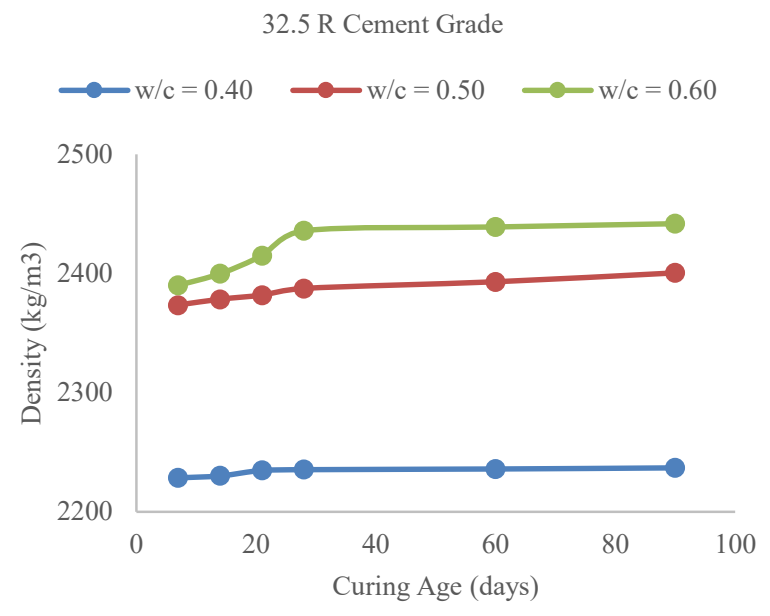

Figure 2: Effects of water/cement ratios on density of the concrete samples.

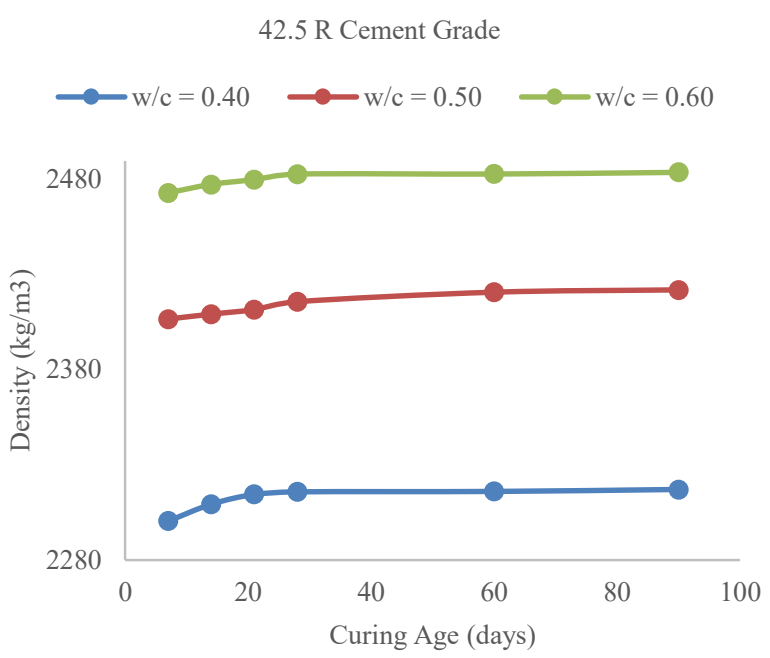

Figure 3: Effects of water/cement ratios on density of the concrete samples.

The increased density may not be unconnected with the fact of increasing workability at higher water/cement ratios (Table 6). According to Neville and Brooks (1987) sufficient workability makes full compaction possible leading to increased density. The increase in density can also be due to the removal of entrapped air in the concrete mix, governed by the grading of the fine aggregate in the mix. The presence of water makes it possible and easier for the voids to be expelled from wet mix than dry one (Neville and Brooks, 1987;

Neville, 2011, and Gambhir, 2013).

\section{F. Compressive Strength of Concrete Specimens made with Different Grades of Portland Limestone Cement}

The pattern of compressive strength development of concrete specimens with grades of cement for water/cement ratios of 0.40, 0.50 and 0.60 are shown in Figures $4-6$. Careful observation of the Figures shows a pattern of slow early strength development and higher rate of late strengths.

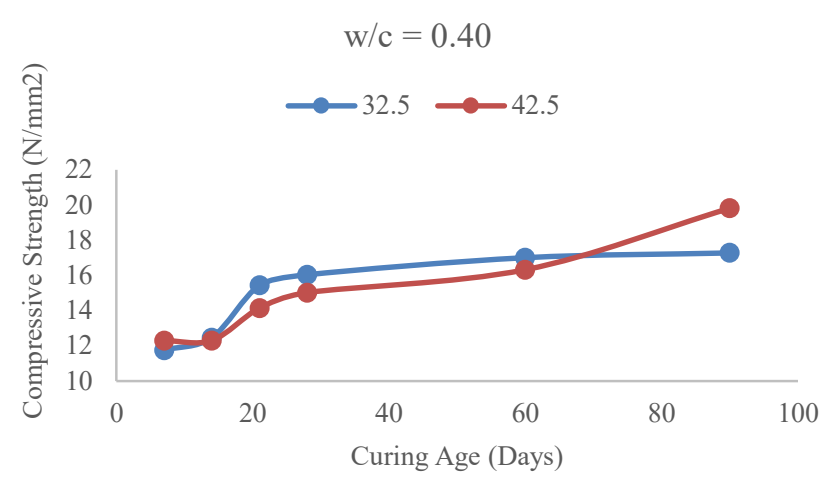

Figure 4: Strength Development for Concrete made from cement of 32.5R and 42.5R at $w / c$ ratio of 0.40 .

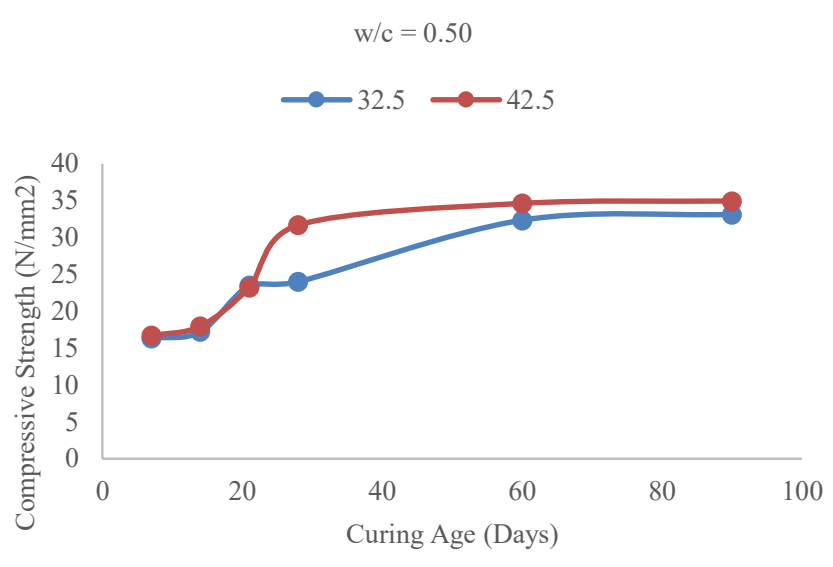

Figure 5: Strength Development for Concrete made from cement of 32.5R and $42.5 R$ at $w / c$ ratio of 0.50 . 


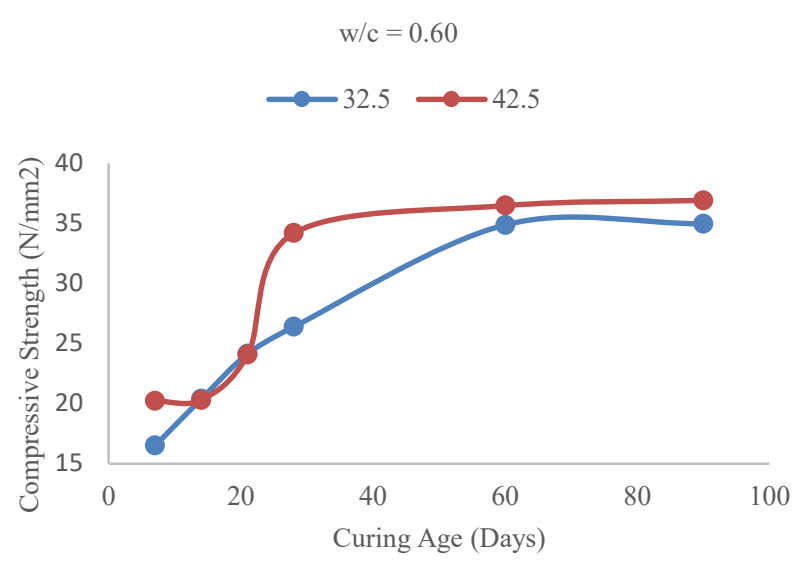

Figure 6: Strength Development for Concrete made from cement of 32.5R and $42.5 R$ at w/c ratio of 0.60 .

However, the concrete specimens with cement grade $32.5 \mathrm{R}$ perform better than concrete made with $42.5 \mathrm{R}$ at all the curing ages up to 60 days, at water/cement ratio of 0.40 . This may be due to the fact that the $32.5 \mathrm{R}$ grade of cement requires a lower amount of water to achieve a standard consistency (Table 5). This, ultimately translates to lower water/cement ratio, setting the stage for higher strength development. Cement grade $32.5 \mathrm{R}$ also sets earlier than $42.5 \mathrm{R}$. The combined effects of these seems to have a greater influence on strength at lower water/cement ratio. However, concrete with cement grade $42.5 \mathrm{R}$ developed higher strength at latter days.

At higher water/cement ratios of 0.50 and 0.60 , concrete specimens made with grade 42.5 developed higher compressive strengths at all the curing days. The numerical values of 28-day compressive strength, being the relevant strength in the design of structural concrete, are shown in Table 10. It can be seen from Table 10 that concrete specimens made with grades 32. $5 \mathrm{R}$ and $42.5 \mathrm{R}$ cement did not have the same 28-day strength. Apart from the fact that specimens with grades $32.5 \mathrm{R}$ developed higher 28-day strength at water/ratio of 0.40 , concrete with $42.5 \mathrm{R}$ cement have higher 28 -day compressive strengths at higher water/cement ratios of 0.50 and 0.60 . This can be as a results of the fact $42.5 \mathrm{R}$ is finer than $32.5 \mathrm{R}$ (Table 5) because it has more specific surface hence it set earlier and thus attained both early and higher strength. This is an indication that concrete produced from $32.5 \mathrm{R}$ and $42.5 \mathrm{R}$ will not have the same 28-day compressive strength.

\begin{tabular}{ccc}
$\begin{array}{c}\text { Table 10: } \mathbf{2 8}^{\text {th }} \\
\text { samples. }\end{array}$ & \multicolumn{2}{c}{ day strength development of the concrete } \\
\hline W/C Ratio & Compressive Strength (N/mm $)$ \\
\cline { 2 - 3 } & $\mathbf{3 2 . 5 ~ R}$ & $\mathbf{4 2 . 5 ~ R}$ \\
\cline { 2 - 3 } 0.40 & 16.04 & 15.02 \\
0.50 & 23.99 & 31.67 \\
0.60 & 26.40 & 34.20 \\
\hline
\end{tabular}

The overall picture is that concrete produced with different cement grade will have differential strength developments, and most importantly, differential 28-day compressive strength. The implication of changing the cement grade during concreting operation to construct the same structural element are many. First, the stripping time for formwork will be different. Thus, if the formwork is stripped at the same time, the portion of the structural member with insufficient strength will collapse. This may spread to other portion of the structure, and the whole structure may collapse. Secondly, the stiffness

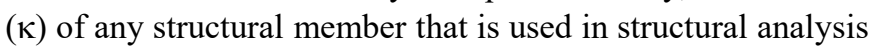
and design is defined as:

$$
\kappa=\frac{E I}{L}
$$

where $\mathrm{E}=$ Youngs Modulus of elasticity, $\mathrm{I}$ = second moment of area of the cross section about the centroidal axis, and $\mathrm{L}=$ the length of the structural member. But the Young modulus $\mathrm{E}$ is a function of the compressive strength. Table 11 (Mosley et al., 2013) shows typical values (cylinder/cube compressive strengths) of E.

\begin{tabular}{cc} 
Table 11: Values of modulus of elasticity of concrete. \\
\hline $\begin{array}{c}\text { Concrete Cube } \\
\text { Strength }\left(\mathbf{N} / \mathbf{m m}^{\mathbf{2}}\right)\end{array}$ & $\begin{array}{c}\text { Modulus of Elasticity } \\
\left(\mathbf{k N} / \mathbf{m m}^{\mathbf{2}}\right)\end{array}$ \\
\hline $20 / 25$ & 30 \\
$25 / 30$ & 31 \\
$30 / 37$ & 33 \\
$35 / 45$ & 35 \\
$40 / 50$ & 36 \\
$50 / 60$ & 37 \\
\hline
\end{tabular}

Thus, mixing cement grades, which are bound to develop two different compressive strengths, to construct the same structural element will result in two different stiffnesses which are not foreseen by any standard, when it is not a composite construction. This is a dangerous situation. Finally, there is differential stress-strain relationship because of incompatibility of deformations. This will lead formation and propagation of crack in the structural element. Collapse will ultimately result.

Also, the results presented and analyses above did not agree with the conclusion made by (Adewole et al., 2015) that a load-bearing building structural members cannot be produced with 1:2:4 mix ratio and $32.5 \mathrm{~N}$ grade of cement. The results presented here show that at water cement/cement ratios of 0.5 and 0.60 , concrete produced with grade 32 . 5R using mix proportion of 1:2: 4 can develop compressive strength for structural application. This agrees with COREN (2019) that, a specified grade of concrete can be produced using any strength class of cement provided the mix design procedure is followed, and backed by adherence to governing standard or code, during production.

Thus, changing of cement grade during concreting operation for the same structural member is not envisage by the code, and will not results in safe and durable structure.

\section{G. Splitting Tensile Strength of Concrete Specimens made with Different Grades of Portland Limestone Cement}

The tensile strength is an important mechanical parameter that allows the determination of degree of susceptibility of concrete to cracks. The pattern of tensile strength, evaluated 
through splitting tensile strength experiment is similar to that of the compressive strength as discussed above in section 3.6. With reference to the discussions of results presented in section 3.6 on compressive strengths pattern, the concrete produced with $42.5 \mathrm{R}$ developed higher splitting tensile strengths than that concrete produced from $32.5 \mathrm{R}$ at all the water/cement ratios and at all the curing ages. Also, splitting tensile strength of the specimens increased with water/cement ratios for all the samples.

\section{CONCLUSION}

From the results and discussions, the followings can be concluded:

1) The cement grade $42.5 \mathrm{R}$ consistently developed higher densities at all the water/cement ratios considered. This may be tantamount to unforeseen additional dead load at the design stage, which would now amount to underestimation of dead load and thus design load.

2) At higher water/cement ratios, the cement grade $42.5 \mathrm{R}$ has densities exceeding the $2400 \mathrm{~kg} / \mathrm{m}^{3}$ recommended by BS 8110 .

3) The concrete specimens produced with cement grades of $32.5 \mathrm{R}$ and $42.5 \mathrm{R}$ have different strength development pattern.

4) The concrete specimens produced with cement grades of 32.5 $\mathrm{R}$ and 42.5 $\mathrm{R}$ developed different 28-day compressive strength.

5) The splitting tensile strength of the specimens followed the pattern of the compressive strength for all the curing days and at all the water cement ratios.

6) Changing the cement grade during concreting for the same structural member is not supported by the national code, and will not result in safe and durable concrete.

Among many parameters and circumstance of usage, this paper presented some relevant structural implications of changing cement grades during concreting. This is with a view to present empirical data that will aid structural decisionmaking process of the technical team or personnel involved in the construction of building and concrete structures. In Nigeria, there are still other parameters that are yet to be investigated in relation to cement grades that are available in Nigeria. They include: strength relations, equations for strength prediction and durability studies of concrete made with $32.5 \mathrm{R}$ and $42.5 \mathrm{R}$, and many more others. They are thus, recommended for future works.

\section{ACKNOWLEDGMENT}

The technical assistance provided by the staff of the Concrete Laboratory, the Department of Civil Engineering, Federal University, Oye-Ekiti, Nigeria, is sincerely acknowledged.

\section{REFERENCES}

Adewole, K. K.; W. O. Ajagbe and I. A. Arasi.
(2015). Determination of appropriate mix ratios for concrete grades using Nigerian Portland-limestone grades 32.5 and 42.5. Leonardo Electronic Journal of Practices and Technologies, 26: 79 - 88.

ACI 116R-90 (1994). Cement and concrete terminology, ACI Manual of Concrete Practice, Part 1: Materials and General Properties of Concrete. American Concrete Institute, Michigan.

ACI (1999). Aggregates for Concrete. ACI Education Bulletin - E1-99, American Concrete Institute, American Concrete Institute, Farmington Hills, Michigan.

Bamforth, P.; D. Chisholm; J. Gibbs and T. Harrison. (2008). Properties of Concrete for use in Eurocode 2 - How to optimise the engineering properties of concrete in design to Eurocode 2. A Cement and Concrete Industry Publication. Available online at: www.concretecentre.com. Accessed on September 15, 2019.

BS 12 (1996). Specification for Portland Cement. British Standard Institution, London.

BS 8110 (1997). Structural use of concrete. British Standard Institution, London.

BS EN 197-1 (2000). Cement, Composition, Specification and Conformity Criteria for Common Cements. British Standard Institution, London.

BS EN 12350 Part 2 (2000). Method for Determination of slump. British Standard Institution, London.

BS EN 196-3 (2005). Determination of Setting Times and Soundness. British Standard Institution, London.

BS 12390: Part 5 (2009) Testing Hardened Concrete: Tensile Splitting Strength of Test Specimens. British Standard Institution, London.

BS EN 12350 Part 6 (2000). Method for Determination of Density. British Standards Institution, London.

BS EN 12620:2002+A1 (2008). Specification for Aggregates from Natural Sources for Concrete. British Standards Institution, London.

BS EN 12390-3 (2009). Testing Hardened Concrete: Compressive Strength of Test Specimens. British Standard Institution, London.

COREN (2016). COREN Position on the Quality of Cement. Available on line at:

https://www.coren.gov.ng/download/category/7-archive. Assessed on 17 December, 2019.

Gambhir, M. L. (2013). Concrete Technology - Theory and Practice. McGraw Hill Higher Education (India) Private Limited, India.

Iowa (2020). Class Notes: C.C. Swan, University of Iowa: Lecture 2: Grain Size Distributions and Soil Particle Characteristics. Available online at:

http://user.engineering.uiowa.edu/ swan/courses/53030/notes /gsd.pdf. Assessed 10 January, 2020.

Joel, M. and Mbapuun, I. D. (2016). Comparative Analysis of The Properties of Concrete Produced with Portland Limestone Cement (Plc) Grade $32.5 \mathrm{~N}$ and 42.5R For Use In Rigid Pavement Work. Global Journal of Engineering Research, 15: 17 - 25. 
Mosley, B.; J. Bungey and R. Hulse. (2013). Reinforced Concrete Design. BookPower and Palmgrave, New York, USA.

Neville, A. M. (2011). Properties of Concrete. Pearson Education, London, UK.

Neville, A. M. and Brooks, J. J. (1987). Concrete Technology. Pearson Educational Ltd, South Africa.

NIS 444-1 (2014). Cement - Part I: Composition and Conformity Criteria for Common Cements. Standard Organization of Nigeria, Abuja, Nigeria.

Odeyemi, S. O.; Z. T. Giwa and R. Abdulwahab. (2019). Building Collapse in Nigeria (2009- 2019), Causes and Remedies - A Review. Journal of Science and Engineering Production, 1(1): 122 - 135.

Omenihu, F. C.; L. O. Onundi and M. A. Alkali. (2016). An Analysis of Building Collapse in Nigeria (1971-2016): Challenges for Stakeholders. University of Maiduguri Annals of Borno, 26: 113 - 140.

Tosun, K.; B. Felekoğlu; B. Baradan and I. A. Altun. (2009). Portland Limestone Cement Part I - Preparation of Cements. Digest, 1337-1355.

Walker, S. and Bloem, D. L. (1961). Discussion of paper by H. J. Gilkey: Water/cement Ratio Versus Strength Another Look. Journal of American Concrete Institute, 58(2): $1851-78$. 